\title{
The Effect of Leisure Meaning on Work Engagement: Teacher Example
}

\author{
Hanife Banu Ataman Yanc1 ${ }^{1} \&$ Suzan Dal ${ }^{2}$ \\ ${ }^{1}$ Division of Physical Education and Sports, Sport Sciences Faculty, Istanbul University-Cerrahpaşa, İstanbul, \\ Turkey \\ ${ }^{2}$ Department of Sport Management, Sport Sciences Faculty, Istanbul University-Cerrahpaşa, İstanbul, Turkey
}

Correspondence: Suzan Dal, Sports Management Department, Sport Sciences Faculty, Istanbul University-Cerrahpaşa, İstanbul, Turkey. E-mail: suzann.dal@gmail.com

Received: July 28, 2020

Accepted: September 16, $2020 \quad$ Online Published: October 29, 2020

doi:10.5539/ies.v13n11p99

URL: https://doi.org/10.5539/ies.v13n11p99

\begin{abstract}
This study aimed to investigate the effects of leisure meanings on work engagement of teachers from different branches. The study sample consisted of 514 teachers working in public schools in Istanbul. The survey method was used for the research, and the survey consisted of three sections: demographic information form, the Meaning of Leisure Scale (MLS), and Work Engagement Scale (WES). The data were analyzed with SPSS statistics package program, and frequency, independent samples t-test, ANOVA, correlation, and regression analysis were performed. The study results suggested a significant and positive correlation between the meaning of leisure and work engagement.
\end{abstract}

Keywords: work engagement, the meaning of leisure, teacher

\section{Introduction}

\subsection{Work Engagement}

Work engagement concept has been popular in the field of positive organizational behavior, especially in the last 20 years. The reason for the increasing number of studies on work engagement in the literature recently is its positive impact on work performance as well as being a good predictor of an individual, team and organizational results (Rich et al., 2010; Christian et al., 2015; Bakker \& Simon 2018; Topaloğlu et al., 2019). Developed by Schaufeli and Bakker (2003), this concept is seen as a mental state in which the employee feels well during the working period as a concept work engagement refers the moods such as being more energetic, enthusiastic, and resolute and reflects the desired employee type in today's business world (Schaufeli et al., 2002; Turgut, 2011; Topaloğlu et al., 2019). Work engagement is defined as "positive and satisfying mood related to work" (Schaufeli et al., 2002) In another definition of the work engagement which is measured with vigor, dedication and absorption, it is associated with one's enjoy and willing to work, which results in productivity at work (Özsoy, Filiz, and Semiz (2013). Rather than a temporary mental state, work engagement does not change in a short time. Work engagement is characterized by vigor, dedication, and absorption, and it a mental state related to work (Schaufeli \& Bakker, 2003). However, it should not be confused with workaholism - the ones who show work engagement are not workaholics and can have fun. The workaholics are obsessed with working to meet the needs stemming from an obligation. Therefore they neglect their daily lives except for the business life (Schaufeli, 2008) Also, those who show work engagement, have great inspiration and do not get tired because working is fun (Bakker, 2009).

The vigor subscale of the work engagement scale can be expressed with high energy retention, not getting tired quickly, and being mentally tough. It involves high motivation and being more vigorous in dealing with difficulties at work (Schaufeli \& Bakker, 2004; Turgut, 2011).

Dedication in work engagement represents a strong commitment to work and encompasses the sense of materiality, enthusiasm, inspiration, pride, and struggle. Besides, working inspires dedicated people, which allow them to do their jobs eagerly and be proud of it (Bakker, 2009; Turgut, 2011).

Absorption in work engagement is one's full concentration on his work. Besides, absorbed people are happy to do their job (Schaufeli et al., 2002; Turgut, 2011). Conceptually, work engagement meets most of the features expected from employees at workplaces. 


\subsection{The Meaning of Leisure}

When the concept of time is considered in terms of its use, it is dealt in two groups as working-time, and non-working time (leisure) (Akgül \& Karaküçük, 2015). The working time includes a series of business activities and the necessary period for this. On the other hand, leisure is described as a period that a person deserves to use it in line with his tendencies and wishes to rest freely, relax, have fun or develop himself (Aytaç, 2002; Karaküçük, 2008).

In the modern mentality of capitalism, leisure is a period used to reproduce labor and work. In terms of capitalism, leisure is a period granted to the employee to increase productivity (Applebaum, 1997). According to another perspective, it is a time that one can use freely to have fun, relax, and improve himself; it is not a preparation for work or off-job time (Karaküçük, 2008). Working time is the period spent for a purpose, whereas leisure is considered a purpose in itself. Working time is the spent time for others, whereas leisure is one's own time, and is enjoyed individually. Leisure is a reward for people. Leisure provides freedom from routine and the opportunity to choose (Savater, 2000, cited by Bozkurt).

Leisure gained different dimensions and meanings due to the control of various power holders. There is an almost complete consensus that the control of the capitalist system has played a significant role in this differentiation (Aytaç, 2004). In the capitalist system, the concept of leisure is no longer a sense and attitude of freedom, but rather a social activity and time boundary with limitations (Güven, 2019).

Trying to explain has also been an attempt to reveal the cultural impact people attribute to leisure (Robust and Henderson, 2013). The meaning of leisure can vary from culture to culture as in systems. Accordingly, there is a need for studies on how it is perceived and defined in different cultures (Arab-Moghaddam et al., 2007; Livengood \& Stodolska, 2004, cited by Kara et al., 2013). In Turkey, the meaning of leisure concept was mostly associated with work, perceived competence, social interaction, and perceived freedom (Gürbüz \& Henderson, 2013). The researches on clarifying the meaning the leisure among people will help fill the gap in the literature (Gürbüz \& Henderson, 2013; Emir et al., 2014; Sarola \& Çimen, 2017; Kara et al., 2018). Also, little is known about how leisure meanings may change or differ about participation in certain recreational activities (Gürbüz \& Henderson, 2013).

In order to help explain how it is perceived in different systems, cultures, and regions, this study examined the relationships between the meaning of leisure and work engagement, which is the objective of this study. Other aims of the study include the description of the differences in the relationships between the meaning of leisure and work engagement in terms of specific variables such as gender, marital status, weekly leisure time, the frequency of participation in a recreational activity, and workplaces recreational organizations.

\section{Method}

\subsection{Universe and Sample}

A relational screening model was used in the study, and the study sample consisted of 514 teachers working in different branches. The data were collected with a simple random sampling method. A total of 514 people participated in the study $(59.7 \%(\mathrm{n}=307)$ female and $40.3 \%(\mathrm{n}=207)$ male $)$

\subsection{Data Collection Instruments}

\subsubsection{Personal Information Form}

Prepared to learn the demographics of the participant employees by the researcher, the form includes information about age, gender, marital status, weekly leisure time, monthly frequency of participation to leisure activities, and the frequency of recreational activities in the workplaces.

\subsubsection{Work Engagement Scale (WES)}

Developed by Schaufeli et al. (2002) and adapted to Turkish to Turgut (2011), the tool measures work engagement. The validity and reliability of the scale were completed by Turgut (2011). The scale consists of 17 questions and three sub-dimensions (Vigor, Dedication, Absorption). The internal consistency value of the scale was .89, and the Cronbach Alpha reliability coefficients for the sub-dimensions were .81 for the vigor sub-dimension; .86 for absorption subdimension and .87 for dedication subdimension. For the current study, it was found .84 for the vigor; .89 for absorption, and .84 for the dedication subscale.

\subsubsection{The Meaning of Leisure Scale (MLS)}

The instrument was developed by Esteve et al. (1999) to determine what people feel when they participate in leisure activities and was adapted to Turkish by Gürbüz, Özdemir, and Karaküçük (2007). It is a six-point Likert 
type scale and consists of 35 questions. The internal consistency of the total scale is 90 . This study was measured as follows: perceived freedom $\mathrm{a}=.83$, social interaction $\mathrm{a}=.78$, discretionary availability $\mathrm{a}=.81$, active-passive participation $\mathrm{a}=.71$, goal orientation $\mathrm{a}=.79$, perceived competence $\mathrm{a}=.77$, intrinsic motivation $\mathrm{a}=.76$ and relation to work $\mathrm{a}=.79$.

\subsection{Statistical Analysis}

The data were analyzed with Statistical Package for the Social Sciences (SPSS). The skewness and kurtosis values were calculated to test whether the data had a normal distribution. The skewness and kurtosis values were between -1 and +1 , which indicated that the data showed normal distribution (Büyüköztürk, 2012). Frequency, correlation, and regression analyzes were performed in the study.

\section{Results}

Table 1. Demographic information of the participants

\begin{tabular}{lccc}
\hline & & Number & Frequency \\
\hline \multirow{3}{*}{ Gender } & Female & 307 & 59.7 \\
& Male & 207 & 40.3 \\
Marital Status & Total & 514 & 100.0 \\
\hline \multirow{4}{*}{ Weekly Leisure } & Single & 320 & 56.8 \\
& Married & 194 & 37.7 \\
& Total & 514 & 100.0 \\
\hline \multirow{3}{*}{ Frequency of participation to leisure activity in a month } & $1-5$ hours & 125 & 24.3 \\
& $6-10$ hours & 157 & 30.5 \\
& $11-15$ hours & 96 & 18.7 \\
& 16 hours and above & 136 & 26.5 \\
& Total & 514 & 100.0 \\
\hline & 1 & 166 & 32.3 \\
& 2 & 124 & 24.1 \\
& 3 & 76 & 14.8 \\
& 4 & 57 & 11.1 \\
& 5 and above & 91 & 17.7 \\
\hline
\end{tabular}

Table 1 demonstrates the demographic information of the participants. In the study, $59.7 \%$ of the participants are female, and $40.3 \%$ are male. The average age is 36.48 years $( \pm 9.92)(\min .20$ max. 65). 56.8\% of the participants are single, $37.7 \%$ are married, and $5.4 \%$ are divorced. In terms of weekly leisure, $24.3 \%$ of the participants had $1-5$ hours, $30.5 \%$ had $6-10$ hours, $18.7 \%$ had $11-115$ hours, $26.5 \% 16$ hours, and above.

For the frequency of participating in leisure activities within one month, $32.3 \%$ participated once, $24.1 \%$ twice, $14.8 \%$ three times, $11.1 \%$, four times, and $17.7 \%$ five times and above. $42.8 \%$ of the participants stated that they had recreational activities in their workplaces, and $57.2 \%$ did not. 
Table 2. Independent t-test results on gender

\begin{tabular}{|c|c|c|c|c|c|c|}
\hline \multirow[t]{2}{*}{ Scales } & \multirow[t]{2}{*}{ Gender } & \multicolumn{2}{|c|}{ Female $\mathrm{N}=307$} & \multicolumn{2}{|c|}{ Male $N=207$} & \multirow[b]{2}{*}{ Independent samples t-test } \\
\hline & & $\mathrm{x}$ & sd & $\mathrm{x}$ & sd & \\
\hline \multirow{3}{*}{ WES } & Vigor & 4.1987 & .88948 & 4.1683 & .95841 & .713 \\
\hline & Absorption & 4.0011 & 1.04362 & 3.8035 & 1.11564 & .041 \\
\hline & Dedication & 4.4704 & 1.11929 & 4.4522 & 1.14992 & .858 \\
\hline \multirow{8}{*}{ MLS } & Active-passive participation & 4.5153 & .72337 & 4.4029 & .80254 & .099 \\
\hline & Social Interaction & 4.7844 & .71182 & 4.6850 & .78710 & .138 \\
\hline & Perceived Competence & 4.6466 & .84676 & 4.4915 & .83803 & .042 \\
\hline & Discretionary Availability & 4.7550 & .71889 & 4.6483 & .82649 & .121 \\
\hline & Perceived Freedom & 4.7270 & .82566 & 4.5623 & .82881 & .027 \\
\hline & Intrinsic motivation & 4.7818 & .77342 & 4.6602 & .88738 & .110 \\
\hline & Goal Orientation & 4.7362 & .84462 & 4.3865 & 1.03388 & .000 \\
\hline & Relation to Work & 4.7544 & .72365 & 4.5324 & .80053 & .001 \\
\hline
\end{tabular}

As seen in Table 2, there is no significant difference in male and female participants' absorption subscale scores. The female participants scored higher than male participants $(\mathrm{p}<.041)$. There are meaningful differences in the sub-dimensions of the perceived competence $(p<0.42)$, perceived freedom $(p<0.7)$, goal orientation $(p<0.00)$, and relation to work $(\mathrm{p}<0.01)$. The mean scores of these sub-dimensions are higher in female participants

Table 3. Independent t-test results on marital status

\begin{tabular}{ccccccc}
\hline & & \multicolumn{2}{c}{ Married N=320 } & \multicolumn{2}{c}{ Single N=194 } & \\
\hline \multirow{3}{*}{ WES } & & $\mathrm{x}$ & $\mathrm{sd}$ & $\mathrm{x}$ & $\mathrm{sd}$ & Independent samples t-test \\
\hline \multirow{4}{*}{ MLS } & Vigor & 4.2911 & .84390 & 4.0137 & 1.00507 & .001 \\
& Absorption & 4.0427 & 1.01147 & 3.7216 & 1.15101 & .001 \\
& Dedication & 4.5625 & 1.02659 & 4.2990 & 1.26986 & .015 \\
& Active-passive participation & 4.4606 & .75911 & 4.4856 & .75652 & .718 \\
& Social Interaction & 4.7219 & .75982 & 4.7814 & .71727 & .379 \\
& Perceived Competence & 4.5297 & .86370 & 4.6740 & .80980 & .061 \\
& Discretionary Availability & 4.6894 & .79205 & 4.7495 & .71875 & .388 \\
& Perceived Freedom & 4.6175 & .84167 & 4.7320 & .80768 & .130 \\
& Intrinsic motivation & 4.7333 & .80775 & 4.7320 & .84850 & .985 \\
& Goal Orientation & 4.5958 & .91498 & 4.5945 & .98314 & .988 \\
& Relation to Work & 4.6344 & .79225 & 4.7155 & .71015 & .243 \\
\hline
\end{tabular}

According to Table 3, there is a significant difference in participants' work engagement regarding marital status. The results indicated that the vigor $(p<.001)$, absorption $(p<.001)$, and dedication $(p<015)$ levels of the single participants were higher than the married participants. No significant difference was found between leisure the sub-dimensions and marital status. 
Table 4. Recreation activities at workplaces

\begin{tabular}{|c|c|c|c|c|c|c|}
\hline & & \multicolumn{2}{|c|}{ Yes $N=220$} & \multicolumn{2}{|c|}{ No $N=294$} & \multirow[b]{2}{*}{ Independent samples t-test } \\
\hline & & $\mathrm{X}$ & $\mathrm{sd}$ & $\mathrm{x}$ & sd & \\
\hline \multirow{3}{*}{ WES } & Vigor & 4.3288 & .89220 & 4.0799 & .92245 & .002 \\
\hline & Absorption & 4.0682 & 1.08101 & 3.8118 & 1.06176 & .007 \\
\hline & Dedication & 4.6273 & 1.08640 & 4.3401 & 1.14919 & .004 \\
\hline \multirow{8}{*}{ MLS } & Active-passive participation & 4.5536 & .76513 & 4.4075 & .74692 & .030 \\
\hline & Social Interaction & 4.8436 & .73597 & 4.6701 & .74237 & .009 \\
\hline & Perceived Competence & 4.6557 & .84799 & 4.5306 & .84174 & .097 \\
\hline & Discretionary Availability & 4.8218 & .73892 & 4.6299 & .77516 & 005 \\
\hline & Perceived Freedom & 4.7491 & .81423 & 4.5946 & .83701 & .037 \\
\hline & Intrinsic motivation & 4.8242 & .84124 & 4.6644 & .80291 & .029 \\
\hline & Goal Orientation & 4.6288 & .91887 & 4.5703 & .95687 & .087 \\
\hline & Relation to Work & 4.7355 & .72175 & 4.6122 & .78891 & .070 \\
\hline
\end{tabular}

In Table 4, significant differences were found in participants' involvement in recreational activities in the institutions or organizations where they work. It was measured that the employees who engaged in recreational activities had higher average scores in the sub-dimensions of WES: vigor $(p<0.02)$, absorption $(p<0.07)$, and dedication $(\mathrm{p}<0.04)$. Similarly, they scored higher in sub-dimensions of the MLS: active-passive participation $(\mathrm{p}<0.30)$, social interaction $(\mathrm{p}<0.42)$, discretionary availability $(\mathrm{p}<0.05)$, perceived freedom $(\mathrm{p}<0.37)$, and intrinsic motivation $(\mathrm{p}<0.29)$.

Table 5. ANOVA results on work engagement and weekly leisure

\begin{tabular}{ccccccc}
\hline \multirow{5}{*}{ Vigor } & Weekly leisure & $\mathrm{N}$ & Avg. & $\mathrm{Sd}$ & $\mathrm{F}(\mathrm{p})$ & Difference (TUKEY) \\
& $1-5$ hours & 125 & 4.2893 & .82337 & & \\
& 6-10 hours & 157 & 4.2325 & .97123 & & - \\
& $11-15$ hours & 96 & 4.1771 & .89665 & $1.740(.158)$ & \\
16 hours and above & 136 & 4.0453 & .94073 & & 16 and above $<1-5,6-10,11-15$ \\
Absorption & $1-5$ hours & 125 & 4.1227 & 1.02087 & & $11-15<1-5,6-10$ \\
& 6-10 hours & 157 & 4.0435 & 1.02430 & $5.253(.001)$ & $6-10<1-5$ \\
& $11-15$ hours & 96 & 3.8403 & 1.10816 & & 16 and above $<1-5,6-10,11-15$ \\
Dedication & 16 hours and above & 136 & 3.6532 & 1.11260 & & $11-15<1-5,6-10$ \\
& $1-5$ hours & 125 & 4.5503 & 1.07361 & & $6-10<1-5$ \\
& $6-10$ hours & 157 & 4.4854 & 1.04981 & 3.016 & $(.030)$ \\
\hline
\end{tabular}

One Way Variance Analysis (ANOVA) was applied to determine the differences in the meaning of leisure scale by weekly leisure periods, and the results are shown in Table 5. The results indicated no difference. Nevertheless, significant differences were found between the groups in absorption and devotion dimensions of the work engagement scale $(\mathrm{p}<0.05)$. The Post-Hoc analysis (Tukey) revealed that the scores of employees $(X=4.12)$ who had 1-5 hours of leisure were higher than those who had 6-10, 11-15, 16, and above hours of leisure. Further, the absorption scores of those with 16 hours or more $(X=3.65)$ leisure were lower than 1-5, 6-10, 11-15 hours of leisure. Similarly, significant differences were determined between the groups in the dedication sub-dimension $(\mathrm{p}<0.05)$. Those who had 1-5 hours of leisure possessed higher dedication scores $(X=4.55)$. Also, those who had 6-10 and 11-15 hours of leisure scored higher than those who had 16 hours or more leisure. 
Table 6. ANOVA results on frequency of monthly participation to recreational activity

\begin{tabular}{|c|c|c|c|c|c|c|}
\hline & Participation frequency & $\mathrm{N}$ & Avg. & $\mathrm{Sd}$ & $\mathrm{F}(\mathrm{p})$ & Difference (TUKEY) \\
\hline \multirow{5}{*}{ Active-passive participation } & 1 & 166 & 4.3398 & .81664 & \multirow{5}{*}{$3.657(.006)$} & \multirow{5}{*}{$1,2<3,4,5$} \\
\hline & 2 & 124 & 4.3903 & .76969 & & \\
\hline & 3 & 76 & 4.5974 & .58651 & & \\
\hline & 4 & 57 & 4.6596 & .68657 & & \\
\hline & 5 and above & 91 & 4.5912 & .75302 & & \\
\hline \multirow{5}{*}{ Social interaction } & 1 & 166 & 4.6735 & .81152 & \multirow{5}{*}{$2.336(.0549)$} & \multirow{5}{*}{-} \\
\hline & 2 & 124 & 4.6387 & .78510 & & \\
\hline & 3 & 76 & 4.8211 & 62617 & & \\
\hline & 4 & 57 & 4.8807 & 60339 & & \\
\hline & 5 and above & 91 & 4.8681 & .70315 & & \\
\hline \multirow{5}{*}{ Perceived competency } & 1 & 166 & 4.5286 & .86182 & \multirow{5}{*}{$1.533(.191)$} & \multirow{5}{*}{-} \\
\hline & 2 & 124 & 4.4919 & .89994 & & \\
\hline & 3 & 76 & 4.6283 & .81291 & & \\
\hline & 4 & 57 & 4.6184 & .71979 & & \\
\hline & 5 and above & 91 & 4.7527 & .82957 & & \\
\hline \multirow{5}{*}{ Discretionary availability } & 1 & 166 & 4.6048 & .76561 & \multirow{5}{*}{$3.169(.014)$} & \multirow{5}{*}{$1,2,3<4,5$} \\
\hline & 2 & 124 & 4.6113 & .86647 & & \\
\hline & 3 & 76 & 4.8316 & 63081 & & \\
\hline & 4 & 57 & 4.8596 & 63015 & & \\
\hline & 5 and above & 91 & 4.8527 & .75885 & & \\
\hline \multirow{5}{*}{ Perceived freedom } & 1 & 166 & 4.5699 & .81549 & \multirow{5}{*}{$2.952(.020)$} & \multirow{5}{*}{$1,2<3,4,5$} \\
\hline & 2 & 124 & 4.5452 & .89491 & & \\
\hline & 3 & 76 & 4.6947 & .84757 & & \\
\hline & 4 & 57 & 4.8632 & .66349 & & \\
\hline & 5 and above & 91 & 4.8286 & .80750 & & \\
\hline \multirow{5}{*}{ Intrinsic motivation } & 1 & 166 & 4.5683 & .87407 & \multirow{5}{*}{$4.576(.001)$} & \multirow{5}{*}{$1,2<3,4,5$} \\
\hline & 2 & 124 & 4.6478 & .92570 & & \\
\hline & 3 & 76 & 4.8728 & .65085 & & \\
\hline & 4 & 57 & 4.9591 & .67574 & & \\
\hline & 5 and above & 91 & 4.8901 & .71674 & & \\
\hline \multirow{5}{*}{ Goal orientation } & 1 & 166 & 4.5281 & .98347 & \multirow{5}{*}{$\begin{array}{l}3.501 \\
(.0089\end{array}$} & \multirow{5}{*}{-} \\
\hline & 2 & 124 & 4.3978 & 1.00736 & & \\
\hline & 3 & 76 & 4.6667 & 78693 & & \\
\hline & 4 & 57 & 4.8012 & .91039 & & \\
\hline & 5 and above & 91 & 4.7985 & .84456 & & \\
\hline \multirow{5}{*}{ Relation to work } & 1 & 166 & 4.5867 & .79059 & \multirow{5}{*}{$\begin{array}{l}3.193 \\
(.013)\end{array}$} & \multirow{5}{*}{$1,2,3<4,5$} \\
\hline & 2 & 124 & 4.5452 & .84482 & & \\
\hline & 3 & 76 & 4.7158 & .63855 & & \\
\hline & 4 & 57 & 4.8947 & .65695 & & \\
\hline & 5 and above & 91 & 4.7846 & .71007 & & \\
\hline
\end{tabular}

Table 6 shows the One-Way Variance Analysis (ANOVA) results that were applied to determine the differences in participants' monthly recreational activity frequencies between two scales. It was found that there was no significant difference in the three sub-dimensions of the WES. However, there were meaningful differences in the subscales of MLS $(p<0.05)$. Significant differences were determined in terms of active-passive participation, discretionary availability, perceived freedom, intrinsic motivation, and the frequency of participation in recreational activities. According to the Post-Hoc analysis (Tukey), in active-passive participation sub-dimension, those who attended recreational activity 3,4 or 5 times monthly had a higher average score than those who attended recreational activity 1 or 2 times $(\mathrm{p}<.006)$. In discretionary availability sub-dimension, those who attended recreational activity 4,5 times monthly scored higher than those who attended recreational activity 1,2,3 times (p $<.014)$. In terms of perceived freedom and intrinsic motivation sub-dimension, those who attended recreational activity 3,4,5 times monthly had a higher average score than those who attended recreational activity 1,2 times 
$[(\mathrm{p}<.020)(\mathrm{p}<.001)]$. Concerning work sub-dimension, those attending recreational activity 4,5 times monthly had a higher average score than those who attended recreational activity $1,2,3(\mathrm{p}<.013)$.

Table 7. Correlation analysis between meaning of leisure and work engagement scales

\begin{tabular}{|c|c|c|c|c|c|c|c|c|c|c|c|c|}
\hline & & 1 & 2 & 3 & 4 & 5 & 6 & 7 & 8 & 9 & 10 & 11 \\
\hline \multirow{3}{*}{ WES } & Vigor & 1 & & & & & & & & & & \\
\hline & Absorption & $.842^{* *}$ & 1 & & & & & & & & & \\
\hline & Dedication & $.844^{* *}$ & $.812^{* *}$ & 1 & & & & & & & & \\
\hline \multirow{8}{*}{ MLS } & Active-passive participation & $.273^{* *}$ & $.245^{* *}$ & $.268^{* *}$ & 1 & & & & & & & \\
\hline & Social Interaction & $.271^{* *}$ & $.257^{* *}$ & $.249^{* *}$ & $.709^{* *}$ & 1 & & & & & & \\
\hline & Perceived Competence & $.189^{* *}$ & $.186^{* *}$ & $.148^{* *}$ & $.587^{* *}$ & $.715^{* *}$ & 1 & & & & & \\
\hline & Discretionary Availability & $.244^{* *}$ & $.250^{* *}$ & $.233^{* *}$ & $.677^{* *}$ & $.736^{* *}$ & $.683^{* *}$ & 1 & & & & \\
\hline & Perceived Freedom & $.177^{* *}$ & $.167^{* *}$ & $.154^{* *}$ & $.609^{* *}$ & $.713^{* *}$ & $.746^{* *}$ & $.735^{* *}$ & 1 & & & \\
\hline & Intrinsic motivation & $.242^{* *}$ & $.223^{* *}$ & $.211^{* *}$ & $.630^{* *}$ & $.644^{* *}$ & $.590^{* *}$ & $.765^{* *}$ & $.633^{* *}$ & 1 & & \\
\hline & Goal Orientation & $.135^{* *}$ & $.160^{* *}$ & $.113^{*}$ & $.478^{* *}$ & $.542^{* *}$ & $.643^{* *}$ & $.584^{* *}$ & $.669^{* *}$ & $.576^{* *}$ & 1 & \\
\hline & Relation to Work & $.225^{* *}$ & $.205^{* *}$ & $.210^{* *}$ & $.611^{* *}$ & $.672^{* *}$ & $.665^{* *}$ & $.744^{* *}$ & $.732^{* *}$ & $.732^{* *}$ & $.735^{* *}$ & 1 \\
\hline
\end{tabular}

Note. ${ }^{* *}: \mathrm{p}<.01, \mathrm{~N}: 514$, r: Pearson Correlation Coefficient, WES: Work Engagement Scale MLS: Meaning of Leisure Scale; **. Correlation is significant at the 0.01 level (2-tailed). *. Correlation is significant at the 0.05 level (2-tailed).

Table 7 shows the correlation analysis results between instruments and sub-dimensions. The vigor and absorption dimensions of the WES are related with each sub-dimension. Similarly, the eight sub-dimensions of MLS are in correlation with each sub-dimension. There were positive and significant correlations between vigor sub-dimension of WES, and active-passive participation $(\mathrm{r}=.273 * *, \mathrm{p}<.01)$, social interaction $(* * \mathrm{r}=.271, \mathrm{p}<.01)$, perceived competence $\left(\mathrm{r}=.189^{* *}, \mathrm{p}<.01\right)$, discretionary availability $\left(\mathrm{r}=.244^{* *}, \mathrm{p}<.01\right)$, perceived freedom $(\mathrm{r}$ $\left.=.177^{* *}, \mathrm{p}<.01\right)$, intrinsic motivation $(\mathrm{r}=.242 * *, \mathrm{p}<.01)$, goal orientation $(\mathrm{r}=.160 * *, \mathrm{p}<.01)$ and relation to work subdimensions $\left(\mathrm{r}=.225^{* *}, \mathrm{p}<.01\right)$. Similar positive and meaningful correlation were found between absorption sub-dimension of WES and active-passive participation $\left(\mathrm{r}=.245^{* *}, \mathrm{p}<.01\right)$, social interaction $\left(\mathrm{r}=.257^{* *}, \mathrm{p}<.01\right)$, perceived competence $\left(\mathrm{r}=.186^{* *} \mathrm{p}<.01\right)$, discretionary availability $(\mathrm{r}=.250 * *, \mathrm{p}<.01)$, perceived freedom $(\mathrm{r}=.167$ $* *, \mathrm{p}<.01)$, intrinsic motivation $(\mathrm{r}=.223 * *, \mathrm{p}<.01)$, goal orientation $\left(\mathrm{r}=.160^{* *}, \mathrm{p}<.01\right)$ and relation to work subdimensions $\left(\mathrm{r}=.205^{* *}, \mathrm{p}<.01\right)$ of MLS. There were positive and significant correlations between dedication sub-dimension of WES and active-passive participation $\left(\mathrm{r}=.268^{* * *}, \mathrm{p}<.01\right)$, social interaction $\left(\mathrm{r}=.249^{* *}, \mathrm{p}<.01\right)$, perceived competence $(\mathrm{r}=.148 * *, \mathrm{p}<.01)$, discretionary availability $(\mathrm{r}=.233 * *, \mathrm{p}<.01)$, perceived freedom $(\mathrm{r}=.154$ ****, $\mathrm{p}<.01)$, intrinsic motivation $\left(\mathrm{r}=.211^{* *}, \mathrm{p}<.01\right)$, goal orientation $(\mathrm{r}=.113 *, \mathrm{p}<.01)$ and relation to work sub-dimensions $(\mathrm{r}=.210 * *, \mathrm{p}<.01)$.

\section{Discussion}

The specification of leisure meanings and work engagement of employees is essential not only for them but also for the organizations they work. The study tried to determine the relationship between teachers' leisure meanings and work engagement. A total of 514 people participated in the study (307 female and 207 male).

In the absorption subdimension of the study, which examined the relationship between work engagement and meaning of leisure, females' scores were higher than male participants. Regarding the meaning of leisure, it was seen that the females scored higher in the perceived competence, perceived freedom, goal orientation, and relation to work sub-dimensions than males. In this sense, it was determined that gender might vary in work engagement and the meaning of leisure. In a review of the literature, Topaloğlu et al. (2019) found that male bank employees' vigor and absorption scores were higher than that of female employees. However, in terms of the meaning of leisure, in their study on adults Dinç et al. (2019), Gürbüz and Henderson (2013), and Kara et al. (2018) revealed that female participants had higher scores than male participants, which is similar to the results of the current study.

Significant differences were found in the work engagement of the participants based on marital status. According to the results, married participants had higher vigor, absorption, and dedication levels than single participants. Similar to this study's results, Topaloğlu et al. (2019) found that married participants had higher work engagement. In the study of Şahin et al. (2018) with health personnel, the level of work engagement of the married healthcare personnel was found to be significantly higher than that of single employees.

In the research, it was pointed out that the employees working at institutions that organized recreational activities 
possessed higher vigor, absorption, and dedication. On the other hand, in the meaning of leisure, the levels of active-passive participation, social interaction, discretionary availability, perceived freedom, and intrinsic motivation of employees at institutions that organized recreational activities were high. In this sense, it was concluded that participants' work engagement and leisure meaning were higher among the employees at the institutions that organized recreational activities. Also, as the number of participants to recreational activity increased, they had higher levels in active-passive participation, discretionary availability, perceived freedom, intrinsic motivation, and relation to work sub-dimensions. Institutions should be encouraged to organize recreational activities to minimize the adverse effects of intense work. Studies have shown that work engagement increases the working performance, and the recreational activities organized by the institutions positively affect performance (Laschinger \& Finegan, 2005; Bakker, 2011; Mokaya \& Gitari, 2012; Upadyaya et al., 2016; Şahin \& Çankır, 2018; Dal \& Yanc1, 2020)

There was no statistically significant difference between leisure meaning and weekly leisure. In terms of a work dedication, it was observed that the participants with more weekly leisure had lower absorption and dedication levels. Thus, it can be inferred that as the participants' weekly leisure increases, they have less absorption and dedication. In light of the findings, organizing recreational activities is more efficient than increasing employees' non-work/leisure activities in prompting employees' work engagement.

There were positive and significant relationships between the vigor, absorption, and dedication subdimensions of the WES and eight sub-dimensions of the MLS, which indicates that the work engagement is positively related to the meaning of leisure time, and as the leisure meaning intensifies, work engagement increases.

The fact that the study was conducted only with teachers is one of the limitations. However, there is no study examining the relationship between work engagement and leisure meaning, which makes this study interesting. The relationships between these two variables in different institutions and cities can be examined in future studies.

\section{References}

Akgül, B. M., \& Karaküçük, S. (2015). Boş Zaman Yönetimi Ölçeği: Geçerlik-Güvenirlik Çalışması. Journal of Human Sciences, 12(2), 1867-1880. https://doi.org/10.14687/ijhs.v12i2.3445

Applebaum, H. (1997). İş Ve Boş Zaman, Çev. N. Saatçioğlu, Cogito, Sayı L2.

Atasoy, L. K., Öncü, E., \& Kılıç, K. S. (2015). Beden Eğitimi Öğretmeni Adaylarında Serbest Zaman Algısı ve Engelleri. 3. Rekreasyon Araştırmaları Kongresi, Eskişehir Anadolu Üniversitesi.

Aytaç, Ö. (2002). Boş Zaman Üzerine Kuramsal Yaklaşımlar. Fırat Üniversitesi Sosyal Bilimler Dergisi Cilt, 12 , 231-260.

Aytaç, Ö. (2004). Kapitalizm ve Hegemonya İlişkileri Bağlamında Boş Zaman. CÜ Sosyal Bilimler Dergisi C, $28,115-138$

Bakker, A. B. (2009). Building Engagement İn The Workplace. In R. J. Burke, \& C. L. Cooper (Eds.), The Peak Performing Organization (pp. 50-72). Oxon, UK: Routledge. https://doi.org/10.4324/9780203971611.ch3

Bakker, A. B. (2011). An Evidence-Based Model Of Work Engagement. Current Directions In Psychological Science, 20(4), 265-269. https://doi.org/10.1177/0963721411414534

Bozkurt, V, (2000). Püritanizmden Hedonizme Yeni Çalışma Etiği. Bursa.

Büyüköztürk, Ş. (2012). Sosyal Bilimler İçin Veri Analizi El Kitabı. Ankara: Pegem Akademi.

Christian, M. S., Garza, A. S., \& Slaughter, J. E. (2011). Work engagement: A quantitative review and test of its relations with task and contextual performance. Personnel psychology, 64(1), 89-136. https://doi.org/10.1111/j.1744-6570.2010.01203.x

Costa, P. L., Passos, A. M., \& Bakker, A. B. (2015). Direct and Contextual İnfluence of Team Conflict on Team Resources, Team Work Engagement, and Team Performance. Negotiation and Conflict Management Research, 8(4), 211-227. https://doi.org/10.1111/ncmr.12061

Dal, S., \& Yancı, H., B. A. (2020). İşyeri Rekreasyonunun Çalışanların İş Performansı Ve Örgütsel Özdeşleşme Üzerine Etkisi. In T. Erdoğan, A. Temizer, \& R. İnan (Eds.), Sosyal Bilimlerde Akademik Çalışmalar.

Dinç, H., Koca, H. B., Poyraz, A., \& Aydemir, K. (2019). Üniversite Öğrencilerinin Boş Zaman Anlamlarının İncelenmesi. Türkiye Spor Bilimleri Dergisi, 3(1), 1-9. https://doi.org/10.32706/tusbid.479316

Emir, E., Gürbüz, B., \& Öncü, E. (2014). Differences in the Perception of Constraints and Motives on Leisure Time Exercise Participation. In International Sport Sciences Congress, November (pp. 7-9). 
Gurbuz, B., \& Henderson, K. (2013). Exploring The Meanings Of Leisure Among Turkish University Students. Croatian Journal of Education: Hrvatski Časopis Za Odgoj I Obrazovanje, 15(4), 927-957.

Güven, U. Z. (2019). Toplumsal Dönüşüm Çerçevesinde Değişen Anlam Ve Kullanımlarıyla Boş Zaman Sosyolojisi. Ankara Üniversitesi Dil Ve Tarih-Coğrafya Fakültesi Dergisi, 59(2), 1125-1148. https://doi.org/10.33171/dtcfjournal.2019.59.2.18

Kara, F. M., Emir, E., Gürbüz, B., \& Öncü, E. (2018). Serbest Zamanın Anlamı: Yetişkin Bireyler Örneği. Spormetre, 16(3), 187-195. https://doi.org/10.1501/Sporm_0000000386

Karaküçük, S. (2008). Rekreasyon Bos Zamanları Degerlendirme. Gazi Kitabevi, Ankara.

Karaküçük, S., \& Gürbüz, B. (2007). Rekreasyon ve Kent (Li) Leşme. Ankara: Gazi Kitabevi.

Kemp, K., \& Pearson, S. (1997). Leisure and Tourism. Great Britain: Longman Press.

Laschinger, H. K. S., \& Finegan, J. (2005). Empowering Nurses for Work Engagement and Health in Hospital Settings. JONA: The Journal of Nursing Administration, 35(10), 439-449. https://doi.org/10.1097/00005110-200510000-00005

Mokaya, S., \& Gitari, J. W. (2012). Effects of Workplace Recreation on Employee Performance: The Case of Kenya Utalii College. International Journal of Humanities and Social Science, 2(3), 176-183.

Özsoy, E., Filiz, B., \& Semiz, T. (2013). İşkoliklik Ve Çalışmaya Tutkunluk Arasındaki İlişkiyi Belirlemeye Yönelik Sağlık Sektöründe Bir Araştırma. Sosyal Ve Beşeri Bilimler Dergisi, 5(2), 59-68.

Passmore, A., \& French, D. (2003). The Nature of Leisure in Adolescence: A Focus Group Study. British Journal of Occupational Therapy, 66(9), 419-426. https://doi.org/10.1177/030802260306600907

Rich, B. L., Lepine, J. A., \& Crawford, E. R. (2010). Job Engagement: Antecedents and Effects on Job $\begin{array}{llll}\text { Performance. Academy of } & \text { Management Journal, }\end{array}$ https://doi.org/10.5465/amj.2010.51468988

Şahin, S., \& Çankır, B. (2018). İş Tatmininin İş Performansına Etkisinde Çalışmaya Tutkunluğun Aracı Rolü: Satış ve Pazarlama Sektöründe Bir Araştırma. International Journal of Economic and Administrative Studies, 17, 389-402. https://doi.org/10.18092/ulikidince.431440

Şahin, S., Yozgat, U., \& Yakși, E. (2018). Çalışmaya Tutkunluk Düzeyinin Hastane Türü, Hastane Lokasyonu Ve Bazı Sosyo-Demografik-Mesleki Özelliklere Göre İncelenmesi. İşletme Bilimi Dergisi, 6(1), 163-183. https://doi.org/10.22139/jobs.361829

Sarol, H., \& Çimen, Z. (2017). Why People Participate Leisure Time Physical Activity: A Turkish Perspective. Pamukkale Journal of Sport Sciences, 8(1), 63-72.

Savater, F. (2000). Gençlerle Politika Üzerine. Çev. Ş. Karadeniz, İletişim Yayınları, İstanbul.

Schaufeli, W. B., \& Bakker, A. (2003). UWES - Utrecht Workengagementscale, Preliminary Manual. Utrecht: Occupational health psychology unit, Utrecht University.

Schaufeli, W. B., Taris, T. W., \& Van Rhenen, W. (2008). Work A Holism, Burn Out, And Engagement: Three Of A Kind Or Three Different Kinds Of Employee Well-Being. Journal of Applied Psychology: An International Review, 57, 173-203. https://doi.org/10.1111/j.1464-0597.2007.00285.x

Topaloğlu, Ö., Sönmez, E. R., \& Yazgan, A. E. (2019). Çalışmaya Tutkunluk ve İş Yaşam Dengesi Arasındaki İlişki: Banka Çalışanları Üzerine. Journal of BRSA Banking \& Financial Markets, 13(1).

Upadyaya, K., Vartiainen, M., \& Salmela-Aro, K. (2016). From Job Demands and Resources to Work Engagement, Burnout, Life Satisfaction, Depressive Symptoms and Occupational Health. Burnout Research, 3(4), 101-108. https://doi.org/10.1016/j.burn.2016.10.001

\section{Copyrights}

Copyright for this article is retained by the author(s), with first publication rights granted to the journal.

This is an open-access article distributed under the terms and conditions of the Creative Commons Attribution license (http://creativecommons.org/licenses/by/4.0/). 